\title{
EFFECT OF WHOLE BUCKWHEAT FLOUR ON TECHNOLOGICAL PROPERTIES OF WHEAT FLOUR AND DOUGH
}

\author{
Elena-Madalina Stefan, Gheorghe Voicu, Gabriel-Alexandru Constantin, \\ George Ipate, Mariana Munteanu \\ University Politehnica of Bucharest, Romania \\ stefanelenamadalina@gmail.com,ghvoicu_2005@yahoo.com,gabriel_alex99@yahoo.com, \\ puiuipate@yahoo.com, munteanumaya@yahoo.com
}

\begin{abstract}
In recent years, due to their chemical composition and high nutritional value, the food products, in which the buckwheat meal is used, have attracted widespread interest, becoming more and more popular. Food products, in which buckwheat meal is used, include pasta, biscuits, bread, cakes, pastry products. The aim of this study was to evaluate the technological parameters (sedimentation index and falling number) for the white wheat flour blends with whole buckwheat flour and rheological properties of dough made from these two types of flour. Thus, the blends were made from wheat flour and whole buckwheat flour in proportion of $10 \%, 20 \%$, $30 \%, 40 \%$ and $50 \%$. Also, the technological properties of $100 \%$ white wheat flour were determined for comparison. The technological properties of mixed flour and dough were determined according to the international standard methods. The addition of whole buckwheat flour to wheat flour influenced the technological and rheological parameters of mixed flours: increasing the amount of whole buckwheat flour (from $10 \%$ to $20 \%, 30 \%$ and $40 \%$ ) causes decrease of the falling number (from $411 \mathrm{~s}, 382 \mathrm{~s}, 249 \mathrm{~s}$ up to $234 \mathrm{~s}$, respectively) and of the sedimentation index (from $28 \mathrm{ml}$ of wheat flour to 22-18 ml). With the increase of whole buckwheat ratio, the water absorption increased significantly from $58.6 \%$ to $79.9 \%$, the dough development time increased significantly from 2.2 minutes to 8.7 minutes but the dough stability decreased from 7.9 minutes to 1.6 minutes. Regarding the Farinograph Quality Number, it is observed that the values increased with whole buckwheat flour addition of $10 \%, 40 \%$ and $50 \%$, but for the samples with addition of $20 \%$ and $30 \%$ this parameter decreased. The obtained results are important for the specialists of the bakery technological process.
\end{abstract}

Keywords: buckwheat, flour, wheat, dough, properties.

\section{Introduction}

Common buckwheat (Fagopyrum esculentum Moench) is a pseudo-cereal, but is usually classified among the cereals because it is used in the same way, but the differences exist in the structure of grain $[1 ; 2]$. There are two commonly grown buckwheat species: common buckwheat (F. esculentum) and tartary buckwheat $(F$. tartaricum). Buckwheat is native to China, and today the largest producing and consuming countries are China, Japan, India, Russia, Poland, Hungary, Italy, Canada, the USA and Brazil [1;2]. In Romania it is not consumed yet on a large scale, more in the North, but it has been observed that the interest is steadly increasing because of the health-promoting properties of its grains.

The buckwheat seed is a dark brown or even dark black achen of triangular shape with a length of 4-9 $\mathrm{mm}$ and the mass of 1000 seeds in the range of 15-35 g [2]. In terms of the chemical composition buckwheat contains: proteins (10-14.5\%), amino acids (lysine, methionine, cysteine and other essential amino acids), starch, lipids, dietary fibre (9.3-10.9\%), mineral elements (Fe, $\mathrm{Se}, \mathrm{Cr}, \mathrm{Zn}, \mathrm{Mg}$, $\mathrm{P}, \mathrm{K}, \mathrm{Na}, \mathrm{Ca}, \mathrm{B}, \mathrm{Sn}, \mathrm{Cu}, \mathrm{Pb}$, which are concentrated mainly in bran), vitamins (whole vitamin complex B - B1, B2, B3, B4, B5, B7-, vitamin E, K) and therapeutic effect components (flavonoids, tannins, phytosterols, phenolic acids and fagopyrins) [1-3]. The protein contained in buckwheat is a high nutritional value compared to to the protein from cereal composition, presenting a valuable nutritional balance. The biological value of buckwheat seed proteins is 93 in comparison to wheat having the biological value 63 [3]. Studies have shown that buckwheat flour has a higher content of $\mathrm{Mg}$ (1113 times), $\mathrm{Li}$ (5-7 times), $\mathrm{Fe}$ (3-4 times), K (2.9-3.6 times) than wheat flour. The carbohydrates (especially strach) are the main constituents of buckwheat seeds, the starch content ranging from 59 to $70 \%$, but the concentration may vary depending on the extraction method and the variety, $[1 ; 2]$. The buckwheat strach is slowly digestible compared to wheat starch that is generally fast digestible. Therefore, by combinig wheat flour with buckwheat flour products are obtained that provide slow digestible starch, giving them special nutritional importance, having similar effects to those of dietery fibers (prevention of colon cancer, lowering the glycemic index, could be nutritionally important diabetics) [3]. Whole buckwheat flour is a natural additive for white wheat flour that could improve the nutritional and functional value of final bakery products [4]. The literature studies showed that the 
good chemical composition of buckwheat is retained in backery products, though in pasta it is used mixed with different types of cereals (wheat, millet, rice, etc.) [5-12].

There are numerous studies that show the effect of buckwheat flour on the parameters of wheat flour (whole wheat flour), on dough, on bakery products and pasta $[4 ; 6 ; 7 ; 13 ; 14]$. In the paper [4] it is shown that in composite flours wheat-buckwheat, the total ash content sgnificantly increased with increased ratio of buckwheat in the proportion of 5 to $30 \%(\mathrm{w} / \mathrm{w})$. Thus, addition of buckwheat decreased the sedimentation index, but not significantly, while the falling number was increased significantly by addition of $\geq 15 \%$ (the falling number increasing at $254 \mathrm{~s}$ for $15 \%$ addition buckwheat to $291 \mathrm{~s}$ for $30 \%$ ). Addition of buckwheat flour changed the parameters of dough by decreasing water absorption (from $54.8 \%$ to $52.6 \%$ ), the dough development time (from 1.7 min to $1.3 \mathrm{~min}$ ), and increasing the dough stability (from $2.7 \mathrm{~min}$ variation of $5.3 \mathrm{~min}$ ), and the farinograph quality number (from 34 to 63). In recent years, due to the chemical composition, nutritive and functional properties (his gluten-free nature), the food products, in which buckwheat meal is used, have attracted widespread interest, becoming more and more popular. Food products, in which buckwheat flour and bran are used, include pasta, bread and different bakery products, cakes, breakfast cereal.

The aim of this study was to evaluate the technological parameters (sedimentation index and falling number) for white wheat flour blends with whole buckwheat flour and rheological properties of dough made from these two types of flour.

\section{Materials and methods}

For the experiments six samples were used: the first used like control was white wheat flour and another five were represented by mixture of wheat flour and whole buckwheat flour in proportion of $10 \%, 20 \%, 30 \%, 40 \%$ and $50 \%$. Wheat flour was provided by a commercial mill and whole buckwheat flour purchased from a local market in Bucharest, Romania. The quality indices of the wheat flour are: moisture content $13.8 \%$, wet gluten $30 \%$, protein $11.3 \%$, fat $0.8 \%$ and for whole buckwheat flour: moisture content $10 \%$, protein $8.4 \%$, fat $0.8 \%$ and fibre $6.6 \%$.

The technological properties of mixed flour and dough were determined according to the international standard methods: for the falling number according to AACC 56-81B, No.1 10711, ISO/DOS 3093 and the device type Falling Number Sadkiewicz was used, the index sedimentation was determined according to ICC No. 166, ISO 5529 and the rheological parameters were evaluated with Brabender Farinograph-E with electronic measuring system, according to AACC No. 54-21, ICC No. 155/1.

The falling number index is the total time (in seconds) required of mixing and falling of a stirrer through a gelling distilled water-flour suspension by a certain distance in a viscometer. Speed liquefaction of flour with the water sample depends on the enzyme activity. The value of the falling number is inverse relationship to the activity of $\alpha$-amylase. The optimal value of the falling number for wheat flour is around of 250 seconds, [15-17]. Flour at 105-220 seconds falling number has a higher amylase activity and requires a correction. Flour at 208-300 seconds falling number has a low amylase activity and bread made from that is not developed, has a small volume and dried [15; 17].

The Zeleny sedimentation index reflects the amount and quality of gluten in flour and is expressed by the volume $(\mathrm{ml})$ of the sediment obtained from a flour suspension in the lactic acid solution. It is indicated that the value of the sedimentation index should be greater than $20 \mathrm{ml}$, [15].

The dough rheological parameters, which were determined, refer to:

- water absorption, which is the amount of water necessary to form a standard dough consistency $-500 \mathrm{FU}$ or $\mathrm{UB}\left(1 \mathrm{BU} \approx 10^{-3} \mathrm{daN} \cdot \mathrm{m}\right)$;

- development time of dough (dough formation) is the period of time that the gluten network is formed and the normal consistency of dough reaches $500 \mathrm{BU}$;

- dough stability is the period of time that the dough keeps the normal consistency with the continuation of the mixing process;

- degree of dough softening is the difference between the standard consistency (500 BU) and the consistency that touches the curve after 12 minutes (or more) of achieving standard consistency; 
- Farinograph Quality Number index (FQN) measures the so-called `strength of flour`, which establishes quality of flour (weak flour or strong flour).

For the falling number and sedimentation index two determinations were made for each sample and the arithmetic mean data was processed. Compared to the average values, the range of the measured values was for the falling number of $\pm(2-5) \mathrm{s}$ and for the sedimentation index of $\pm(0-2) \mathrm{ml}$. For the farinograph parameters (the dough rheological parameters) one determination for each sample was made. Processing of the experimental data was performed using the application package MS Office Excel.

\section{Results and discussion}

The results obtained from the experiments on variation of the falling number index and sedimentation index are presented in Table 1 and Figure 1 . Wheat flour was characterized with a high falling number index (452 s), which indicated a low amylases activity. In this case it is recommended to add malt or malted flour in order to increase the $\alpha$-amylasic activity and to improve wheat flour baking properties [5].

Values of falling number and sedimentation indices

Table 1

\begin{tabular}{|c|c|c|}
\hline Flour & $\begin{array}{c}\text { Falling number index, } \\
\text { s }\end{array}$ & $\begin{array}{c}\text { Zeleny sedimentation } \\
\text { index, ml }\end{array}$ \\
\hline Wheat flour $100 \%$ & 452 & 28 \\
\hline Buckwheat $10 \%$ & 411 & 22 \\
\hline Buckwheat $20 \%$ & 382 & 20 \\
\hline Buckwheat $30 \%$ & 249 & 21 \\
\hline Buckwheat $40 \%$ & 234 & 19 \\
\hline Buckwheat $50 \%$ & 89 & 18 \\
\hline
\end{tabular}

The falling number value decreased to $411 \mathrm{~s}, 382 \mathrm{~s}, 249 \mathrm{~s}$ and $234 \mathrm{~s}$, when $10 \%, 20 \%, 30 \%$ and respectively $40 \%$ of wheat flour was replaced with whole buckwheat flour. This indicates that whole buckwheat flour can be used as an additive to correct the $\alpha$-amylase activity of wheat flour in order to improve the quality and obtain good bakery products. These results are in agreement with those reported in the paper [5]. By the addition of buckwheat flour the falling number decreases approximately linearly (Figure 1). The linear variation of the falling number with the percentage of buckwheat meal is characterized by the $R^{2}=0.938$ value of the correlation coefficient.
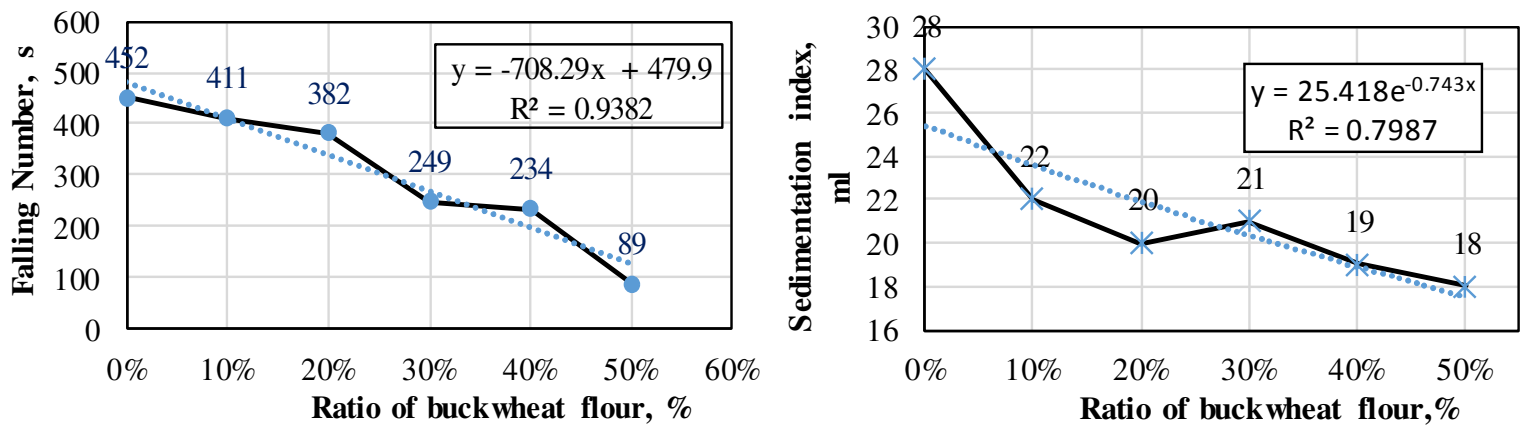

Fig. 1. Variation of falling number and sedimentation index with whole buckwheat flour ratio

Regarding the sedimentation index (test Zeleny), from Table 1 and Figure 2 it is observed that the values decreased from $28 \mathrm{ml}$ for wheat flour to $22-18 \mathrm{ml}$ with increased ratio of whole buckwheat flour.

Thus, by increasing the content of whole buckwheat flour in the mixture with wheat flour, the content of wheat gluten proteins is reduced, the quality of gluten decreases. Figure 1 shows an approximately exponential decreasing variation of the sedimentation index characterized by a $R^{2}=0.798$ correlation coefficient. 
The values of rheological parameters for all types of dough made of mixed flours are presented in Table 2. The variation of these parameters is shown in Figure 2 and 3.

Table 2

Values of rheological parameters

\begin{tabular}{|c|c|c|c|c|c|}
\hline Flour & $\begin{array}{c}\text { Water } \\
\text { absorption, \% }\end{array}$ & $\begin{array}{c}\text { Dough } \\
\text { development } \\
\text { time, min }\end{array}$ & $\begin{array}{c}\text { Dough } \\
\text { Stability, } \\
\text { min }\end{array}$ & $\begin{array}{c}\text { Degree of } \\
\text { softening 10 } \\
\text { min after test } \\
\text { starting, BU }\end{array}$ & $\begin{array}{c}\text { Farinograph } \\
\text { Quality } \\
\text { Number }\end{array}$ \\
\hline Wheat flour 100\% & 58.6 & 2.2 & 7.9 & 40 & 77 \\
\hline Buckwheat 10\% & 61.2 & 5.5 & 6.2 & 61 & 80 \\
\hline Buckwheat 20\% & 67.8 & 5.2 & 3.1 & 151 & 61 \\
\hline Buckwheat 30\% & 75.8 & 6.0 & 2.1 & 116 & 72 \\
\hline Buckwheat 40\% & 79.2 & 7.5 & 1.3 & 82 & 86 \\
\hline Buckwheat 50\% & 79.9 & 8.7 & 1.6 & 56 & 95 \\
\hline
\end{tabular}

The results show that the addition of whole buckwheat flour to white wheat flour, in different proportions, changed the rheological parameters. Water absorption increased significantly with the increase of whole buckwheat ratio. The similar result was noticed in the paper [13], where whole buckwheat flour was used. In contrast to the papers [4; 18], in which flour was used obtained by milling of buckwheat grains after husking light buckwheat flour, the water absorption decreased with increased content of buckwheat flour. It is known that the main component responsible for wheat flour water absorption is gluten, but as buckwheat is gluten-free, then higher absorption properties are probably due to higher content of fibres (fibres provide good properties of water absorption).
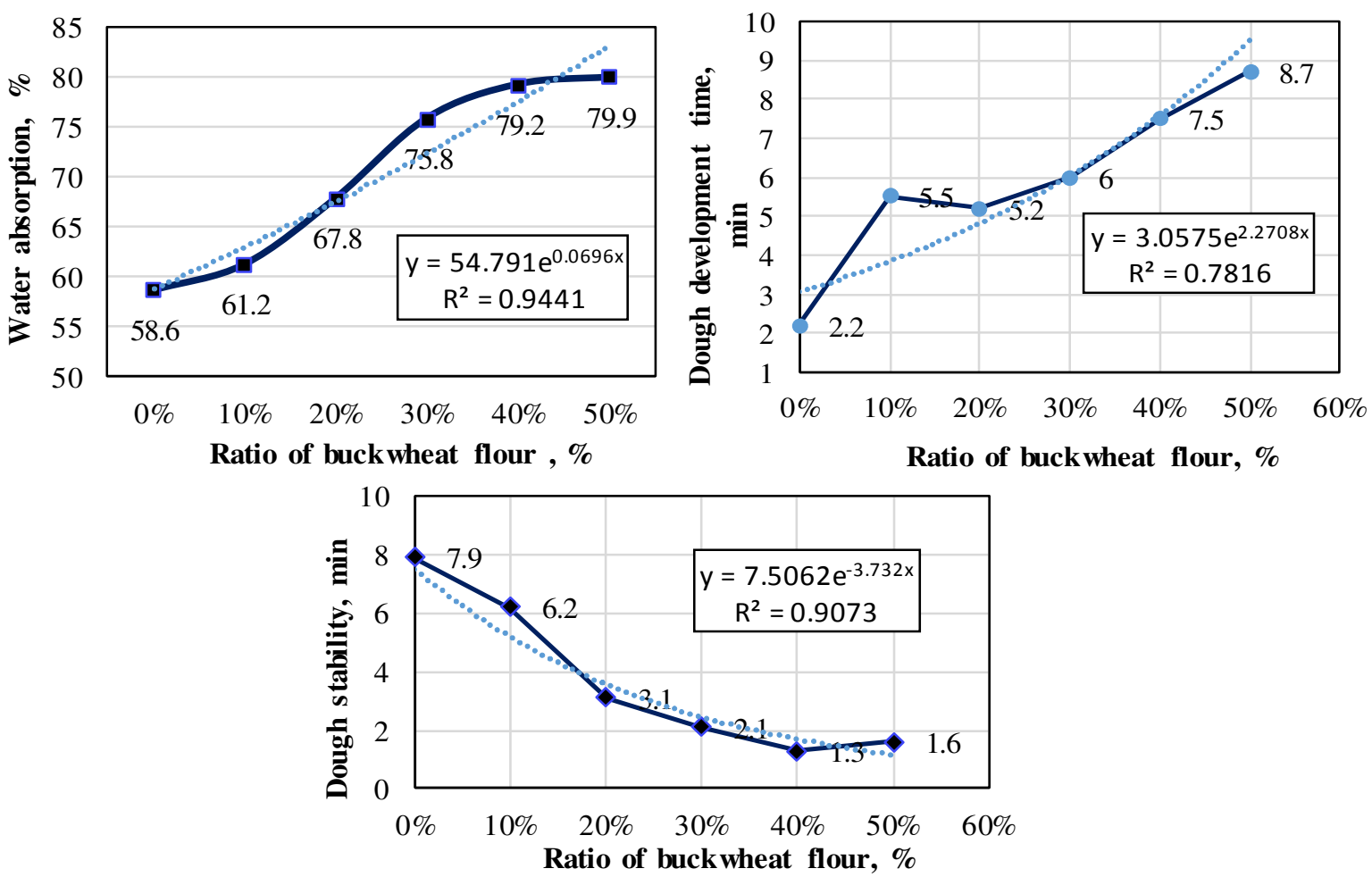

Fig. 2. Variation of water absorption, dough development time and dough stability with whole buckwheat flour ratio

The dough development time increased significantly with addition of whole buckwheat flour. The addition of buckwheat flour up to $50 \%$ increased the dough development time to $8.7 \mathrm{~min}$, compared with the sample of $100 \%$ wheat flour, where it was of $2.2 \mathrm{~min}$. the same trend was also reported in $[5 ; 13]$, but contrary to the papers $[4 ; 18]$, where a non-significantly decrease of dough development time was observed. The mixture wheat-buckwheat takes longer time to form, because buckwheat flour particles need longer time to hydrate. 
The dough stability decreased significantly after addition of $20 \%$ whole buckwheat flour (from $7.9 \mathrm{~min}$ to $3.1 \mathrm{~min}$, reaching of $1.6 \mathrm{~min}$ for the addition of $50 \%$ buckwheat). The low degree of softening values was for the sample containing $10 \%, 40 \%$ and $50 \%$ whole buckwheat flour. But these values were higher than the sample of $100 \%$ wheat flour. The sample containing $20 \%$ and $30 \%$ whole buckwheat flour has recorded a high value, about $151 \mathrm{BU}$ and $116 \mathrm{BU}$, respectively, compared to $40 \mathrm{BU}$ of $100 \%$ wheat flour sample. The whole buckwheat flour addition of $10 \%, 40 \%$ and $50 \%$ increased the Farinograph Quality Number, but the samples with addition of $20 \%$ and $30 \%$ decreased this parameter. It can be observed that these samples are the same that have recorded high values of the softening degree. The Farinograph Quality Number influences the dough softening parameters [4].

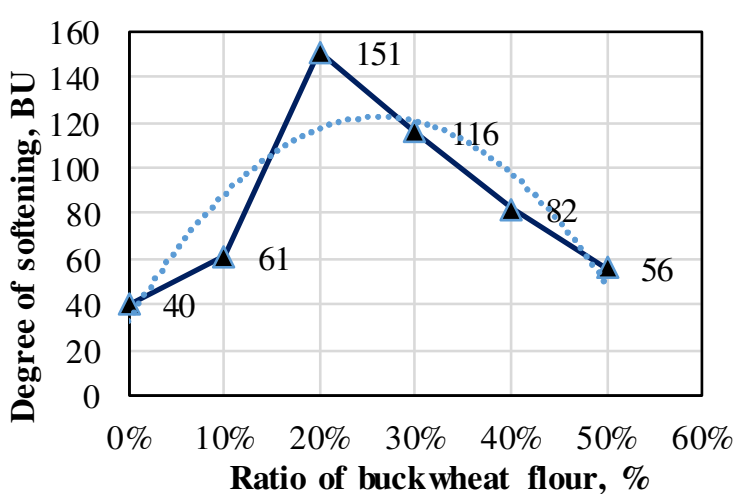

Fig. 3. Variation of degree of softening and Farinograph Quality Number with whole buckwheat flour ratio

\section{Conclusions}

1. Whole buckwheat flour addition in white wheat flour had considerable effects on the technological properties of wheat flour and dough.

2. Whole buckwheat flour can be used as an additive to correct the $\alpha$-amylase activity of wheat flour in order to improve the quality and obtain good bakery products.

3. The optimal value of the falling number (recommended to be around $250 \mathrm{~s}$ ) was obtained by adding $30 \%$ and $40 \%$ buckwheat flour (249 sand 234 s).

4. By mixing whole buckwheat flour with wheat flour, the content of wheat gluten proteins can be reduced, the quality of gluten decreases: the sedimentation index decreases from $28 \mathrm{ml}$ of wheat flour to $22-18 \mathrm{ml}$ with the addition of buckwheat flour from $10 \%$ to $50 \%$.

5. Water absorption increased significantly within the range of 58.6-79.9\% with the increase of whole buckwheat ratio from $0 \%$ to $50 \%$, which could mean a lower baking time of the bakery products, because moist doughs are baked quickly due to the increased enthalpy of water with increasing the temperature values.

6. With the increase of whole buckwheat ratio, the dough development time increased significantly from 2.2 minutes to 8.7 minutes, the dough stability decreased from 7.9 minutes to 1.6 minutes and the Farinograph Quality Number values increased with whole buckwheat flour addition of $10 \%, 40 \%$ and $50 \%$, but the samples with addition of $20 \%$ and $30 \%$ decreased this parameter.

7. The technological parameters (sedimentation index and falling number) for white wheat flour blends with whole buckwheat flour and rheological properties of dough made from these two types of flour depend on the proportion of participation of each type of flour and their compositional structure.

\section{References}

[1] Campbell C.G. Buckwheat. Fagopyrum esculentum Moench. Promoting the conservation and use of underutilized and neglected crops. 19. Institute of Plant Genetics and Crop Plant Research, Gatersleben/International Plant Genetic Resources Institute, Rome, Italy, 1997.

[2] Colin W., Harold C., Charles E.W. (editors). Encyclopedia of Grain Science, Elsevier Academic Press, 2004. 
[3] Bonafaccia G., Gambelli L., Fabjan N., Kreft I.. Trace elements in flour and bran from common and tartary buckwheat. Food Chemistry, vol. 83, 2003b, pp. 1-5.

[4] Gavurníková S., Havrlentová M., Mendel L., Čičová I., Bieliková M., Kraic J. Parameters of wheat flour, dough, and bread fortified by buckwheat and millet flours. Agriculture (Pol’nohospodárstvo), vol. 57, 2011, no. 4, pp. 144-153.

[5] Bonafaccia G., Kreft I. Technological and qualitative characteristics of food products made with buckwheat. Fagopyrum vol. 14, 1994, pp. 35-42.

[6] Yıldız G., Bilgiçli N. Effects of whole buckwheat flour on physical, chemical, and sensory properties of flat bread, Lavaş. Czech J. Food.Sci., vol. 30, 2012, pp. 534-540.

[7] Krupa-Kozak U., Wronkowska M., Soral-Śmietana M. Effect of buckwheat flour on microelements and proteins contents in gluten-free bread. Czech J. Food Sci., vol. 29, 2011, pp. 103-108.

[8] Christa K., Soral-Śmietana M. Buckwheat grains and buckwheat products - nutritional and prophylactic value of their components - a review. Czech Journal of Food Sciences, vol. 26, 2008, pp. 153-162

[9] Dvořakova P., Burešova I., Kračmar S. Textural properties of bread formulations based on buckwheat and rye fl our. Acta univ. agric. et silvic. Mendel. Brun., LX, 2012, pp. 61-68.

[10] Balijeet S.Y, Ritika B.Y., Roshan L.Y. Studies on functional properties and incorporation of buckwheat flour for biscuit making. International Food Research Journal, vol. 17, 2010, pp. 1067-1076.

[11] Wronkowska M., Troszyńska A., Soral-Śmietana M., A.Wołejszo. Effects of buckwheat flour (Fagopyrum Esculentum Moench) on the quality of gluten-free bread. Polish Journal of Food and Nutrition Sciences, vol. 58, 2008, pp. 211-216.

[12] Ganesh J. Bhavsar1, A. R. Sawate1, Kshirsagar R. B.1, Vijaykumar M. Chappalwar. Studies on Physico-Chemical Chracteristics of Buckwheat and its Exploration in Bread as Functional Food. International Journal of Engineering Research \& Technology (IJERT), vol. 2, 2013, pp. 3971-3980.

[13] Özer M. S., Kola O., Duran H. Effects of buckwheat flour combining phospholipase or DATEM on dough properties. Journal of Food, Agriculture \& Environment, vol.8, 2010, pp. 13-16.

[14] George E. Inglett, Jingyuan Xu, David G. Stevenson, and Diejun Chen. Rheological and Pasting Properties of Buckwheat (Fagopyrum esculentum Möench) Flours With and Without Jet-Cooking Cereal Chem, vol. 86, 2009, pp. 1-6.

[15] Banu C. Tratat de industrie alimentară. Tehnologii alimentare, Editura ASAB, Bucuresti, 2009.

[16] Edwards W.P. The Science of Bakery Products, The Royal Society of Chemistry, 2007.

[17] Iorga E., Belc N., Stancov A., Campeanu G. Improvement of Falling Number on Romanian wheat Flours, Roum. Biotechnol. Lett., vol.7, 2002, pp. 635-646.

[18] Nedeljković N. et al.. Rheological properties and mineral content of buckwheat enriched wholegrain wheat pasta Chem. Ind. Chem. Eng. Q., vol. 20, 2014, pp. 135-142. 